\title{
Kritik Hermeneutika Filsafat Hans Georg Gadamer
}

\author{
Hayatuddiniyah ${ }^{1}$ \\ 1Program Studi Interdisciplinary Islamic Studies, Pascasarjana UIN Sunan Kalijaga Yogyakarta, \\ Indonesia \\ E-mail: hayatuddiniyahfz@gmail.com¹
}

\begin{abstract}
Abstrak
Manusia dalam dunia filsafat tidak terlepas dari istilah "menafsirkan" atau "menginterpretasi", yang biasa disebut dengan hermeneutika. Salah satu filsuf yang mengkaji hermeneutika tersebut adalah Hans Georg Gadamer (1900-2002) yang menawarkan konsep peleburan cakrawala. Artikel ini bertujuan untuk mengetahui secara lebih komprehensif konsep peleburan cakrawala yang ditawarkan oleh Hans Georg Gadamer dalam bidang kajian hermeneutika filsafat. Metode yang digunakan dalam artikel ini adalah metode kualitatif dengan jenis studi pustaka, sedangkan teknik analisis yang digunakan adalah analisis kritik. Hasil dalam artikel ini adalah konsep peleburan cakrawala Hans Georg Gadamer yang menekankan bahwa cakrawala seseorang pada masa ini terjadi atas dasar cakrawala yang la miliki pada masa lalu, atau dengan kata lain cakrawala yang saat ini dimiliki oleh setiap orang merupakan hasil terbentuknya akumulasi berbagai cakrawala pada masa lalu dalam gerak melingkar yang terusmenerus. Sebuah peleburan cakrawala memiliki persimpangan konsep yang berbeda, seperti yang dikatakan Jean Grondin bahwa dalam memahami cakrawala pada masa lalu membutuhkan pengertian dan pemahaman manusia terhadap cakrawala masa sekarang. Kedua konsep peleburan cakrawala tersebut tentu memiliki alasan-alasan tersendiri mengenai hal yang lebih diterima dan dibutuhkan oleh manusia pada masa sekarang.
\end{abstract}

Kata kunci: filsafat; hermeneutika; Hans Georg Gadamer.

\begin{abstract}
Humans in the world of philosophy can't be separated from "interpreting" or what is called hermeneutics. One of the philosophers who studied hermeneutics was Hans Georg Gadamer (1900-2002) who offered the concept of fusion horizons. This article aims to find out more comprehensively how the concept of fusion horizons offered by Hans Georg Gadamer in the field of philosophical hermeneutic studies. The method used in this article is a qualitative method with the type of literature study, while the analysis technique used is critical analysis. The result in this article is the concept of fusion horizons. Hans Georg Gadamer emphasizes that a person's present horizon occurs on the basis of the horizon that he had in the past, or in other words the horizon currently owned by everyone is the result of its formation as an accumulation of various horizons in the past, in a continuous circular motion. And in a fusion the horizons have different intersections of concepts, as Jean Grondin said that understanding the horizon in the past requires human understanding of the horizon of the present. So that from the two concepts of fusion of the horizon have their own reasons which are more accepted and needed by humans today.
\end{abstract}

Keywords: philosophy; hermeneutics; Hans Georg Gadamer.

\section{Pendahuluan}

Berbicara persoalan filsafat sama halnya berbicara mengenai manusia. Manusia yang dilahirkan dengan akal budi, kesadaran dan hasrat pada dasarnya adalah makhluk pencari kebenaran. Hal tersebut berarti manusia tidak akan pernah puas dengan sesuatu yang sudah ada di sekelilingnya, sehingga terus-menerus mencari sebuah kebenaran dengan pertanyaanpertanyaan yang selalu muncul dari pikiran manusia tersebut. Selain itu, filsafat juga akan menggerakkan pikiran manusia untuk terus-menerus mencari suatu makna yang hakiki yang diinginkannya dan mungkin dibutuhkan dalam menjalani kehidupan. Sehingga dalam proses itu, secara tidak langsung seseorang dapat menyebut dirinya sedang berfilsafat. Dari aspek 
kebahasaan, istilah filsafat berasal dari bahasa Yunani yaitu Philos dan Shopein (Shofia). Philos berarti cinta; mencintai; mencari, sedangkan Shofia berarti kebijaksanaan atau kebenaran, maka dari itu istilah filsafat berarti orang yang sedang mencari kebenaran atau kebijaksanaan (Khalif, 2019). Selain itu, berdasarkan Kamus Lengkap Bahasa Indonesia, filsafat berarti pengetahuan dan penyelidikan dengan akal budi berkenaan dengan hakikat (S.S, 2005). Maka dari itu, berdasarkan definisi di atas jelas disebutkan bahwa filsafat adalah cinta terhadap kebijaksanaan dan berpikir atas segala pertanyaan-pertanyaan keingintahuan dengan menggunakan seluruh akal budinya.

Dalam dunia filsafat, selain manusia disibukkan dengan pertanyaan-pertanyaan untuk menemukan kebenaran, manusia juga tidak terlepas dari yang namanya menafsirkan atau menginterpretasi, dengan kata lain manusia selalu terlibat dari aktivitas menafsir dan memaknai suatu simbol tertentu. Maka dari itu, apabila dikaitkan dengan dunia filsafat, kegiatan atau kebiasaan manusia yang selalu menafsirkan atau disebut dengan menginterpretasi ini dapat disebut dengan hermeneutika (hermenutics). Hermeneutika secara sederhana berarti ilmu untuk mengetahui maksud atau makna yang terkandung dalam kata-kata atau suatu ungkapan (Wahid, 2017). Adapun hermeneutika jika dilihat dari sejarah yang lebih tepatnya pada hermeneutika dalam istilah Yunani yakni hermeneuin mengingatkan pada seorang tokoh mitologis yang bernama Hermes. Hermes memiliki tugas untuk menerjemahkan atau menafsirkan pesan-pesan dari Dewa di gunung Olympus, Hermes ini menerjemahkan pesan tersebut menggunakan bahasa-bahasa yang tentunya mudah dimengerti oleh masyarakat setempat pada umumnya. Hermes ini juga mampu memberikan pemaknaan dan menginterpretasikan pesan-pesan tersebut dan mudah diterima oleh masyarakat pada waktu itu. Sehingga dengan adanya kejadian ini, Hermes dianggap sebagai simbol bagi orang yang buta yang tidak tahu apa-apa. Berkat kemampuan yang dimiliki Hermes dalam lingkup hermeneutika, proses mengubah sesuatu atau situasi dari tidak tahu menjadi tahu (Gazali, 2012). Maka dari itu, dalam hal ini manusia memiliki posisi sebagai orang yang ingin terus mengetahui makna atau tafsir dari sesuatu, serta dapat dipahami bahwa hermeneutika adalah suatu cara untuk menjelaskan atau menafsirkan sesuatu dengan tujuan agar orang-orang saling mengerti. Hermeneutika ini juga dapat dipahami dengan sebuah pemaknaan terhadap sesuatu yang tersimpan dan tersembunyi. Hal ini seperti yang dilansir dari Kompasiana bahwa tujuan hermeneutika adalah menciptakan pemahaman terhadap karya dan tindakan manusia dengan menginterpretasikan sifat-sifat dan arti pentingnya. Pernyataan tersebut dapat berarti memahami perasaan dan maksud orang lain, memahami makna suatu peristiwa, menerjemahkan tindakan suatu kelompok, atau mengungkap makna dari suatu tulisan (Ariani, 2021).

Hermeneutika dalam dunia filsafat juga disebut sebagai bangunan epistimologi yang muncul bukan sebagai tradisi berpikir mandiri, melainkan hasil reaksi, dan koreksi dari beberapa pemikiran (Hasanah, 2017). Adapun dalam konteks ini banyak sekali tokoh yang mengkaji hermeneutika dari berbagai sudut pandang, salah satunya adalah pemikiran Hans Georg Gadamer (1900-2002). Hans Georg Gadamer merupakan seorang filsuf yang cukup terkenal di dunia filsafat yang berasal dari Jerman (Gazali, 2012). Hans Georg Gadamer atau yang biasa disapa dengan Gadamer ini dilahirkan di kota Breslau pada 11 Februari 1900 masehi dan telah meninggal pada tahun 2002 tepatnya pada 13 Maret. Hans Georg Gadamer terlahir sebagai anak kedua dan dibesarkan oleh ibu dan ayahnya yang bernama Emma Caroline Johanna Gewiese (1869-1904) dan Dr. Johannes Gadamer (1867-1928) di kota Marburg, sebuah kota di bagian selatan Jerman (Liana, 2011). Hans Georg Gadamer memiliki fokus kajian pada bidang filsafat hermeneutic. la memulai karirnya sebagai seorang filsuf dari Universitas Breslau pada Nikolai Hartman dan Martin Heidegger dan menjelang masa pensiun karirnya, Hans Georg Gadamer menghasilkan karya yang cukup besar dan dikenal banyak orang pada waktu itu, karya tersebut adalah sebuah buku Wahrheit und Mehtode (Truth and Method, 1960). Hans Georg Gadamer memiliki beberapa konsep terhadap kajian hermeneutika, salah satunya ialah terhadap konsep peleburan cakrawala atau asimilasi horizon. Menurutnya, horison atau cakrawala sangat diperlukan manusia dalam proses pemahaman kesadaran sejarah-efektif, yang bearti manusia berada dalam arus tradisi makna tertentu (Kaprisma, 2011).

Terlepas dari yang dipaparkan di atas terhadap kajian hermeneutika ini, khususnya pada persoalan peleburan cakrawala, tentu memiliki beberapa persimpangan atau konsep yang berbeda, bahkan konsep yang bertolak belakang, baik itu dari segi faktor ataupun yang lainnya. Misal dalam beberapa persimpangan atau konsep tersebut memiliki tolok ukur mengenai yang lebih diterima dan dibutuhkan oleh manusia pada masa sekarang. Seperti yang disebutkan 
Hans Georg Gadamer bahwa dalam proses peleburan cakrawala dibutuhkan pemahaman kesadaran sejarah-efektif. Lain halnya dengan Paul Ricoeur yang meyakini bahwa dalam proses cakrawala, seseorang membutuhkan bahasa sebagai alat untuk membicarakan atau memahami sesuatu, karena menurutnya ekspresi-ekspresi kehidupan seseorang ditentukan oleh linguistik atau bahasa dan seluruh aktivitas yang dijalani manusia selalu tidak lepas dari bahasa dan menjadi syarat utama bagi pengalaman dan pemahaman manusia, bahkan suatu seni yang ditampilkan secara visual pun menggunakan bahasa (Thalib, 2018). Secara sederhananya dapat dicontohkan seperti proses bayi yang membutuhkan susu. Pada saat la membutuhkan susu dengan ibunya, la akan memanggil atau berbicara dengan bahasa ciri khas bayi pada umumnya, seperti "mama", "maa", atau lain sebagainya, sehinga dengan la berbahasa seperti itu maka sang ibu akan mengerti dan memahami bahwa si bayi sedang membutuhkan susu.

Maka dari itu, berdasarkan uraian di atas, penulis dalam artikel ini tertarik untuk mengulas lebih dalam tentang corak pemikiran Hans Georg Gadamer, yaitu dengan mengetahui secara lebih komprehensif tentang konsep peleburan cakrawala yang ditawarkan oleh Hans Georg Gadamer. Menurut penulis, konsep peleburan cakrawala Hans Georg Gadamer ini cukup menarik dan menjadi penting untuk dikaji karena Hans Georg Gadamer menitikberatkan manusia sebagai makhluk historis. Menurutnya dalam menginterpretasikan suatu objek bergantung dari aspek historis dan sudut pandang masing-masing manusia dengan menggunakan fenomenologi fusion of horizon. Selain mengulas lebih dalam tentang corak pemikiran Hans Georg Gadamer, dalam artikel ini penulis juga menyajikan kritik dan penulis mencoba menganalisa konsep peleburan cakrawala yang ditawarkan oleh Hans Georg Gadamer ini dengan memaparkan konsep lain yang hampir sama dengan konsep peleburan cakrawala yang ditawarkan oleh Hans Georg Gadamer.

Apabila disandingkan dalam konteks keindonesiaan, konsep Hans Georg Gadamer ini dapat digambarkan melalui fenomena politik atau kenegaraan di Indonesia. Fenomena politik atau kenegaraan yang mengusung konsep negara kebangsaan (nation state) ini akan terus berkembang jika realitas dan tradisi politik yang ada saat ini terus diinterpretasikan, diinternalisasikan, serta disosialisasikan. Akan tetapi jika merujuk kepada konsep Hans Georg Gadamer, makna nation state bukan lagi seperti yang dimaksud oleh pendiri bangsa terdahulu, melainkan sudah dimaknai berbeda di mata generasi muda saat ini karena pengaruh dinamika zaman yang tengah berkembang. Maka dari itu, dengan menggunakan konsep Hans Georg Gadamer ini, hal-hal yang menjadi cita dan harapan para pendiri bangsa dapat terwujud. Terwujudnya cita dan harapan demi keberlangsungan NKRI sebagai nation state tersebut tentunya tergantung dari pemaknaan dan pemahaman generasi muda saat ini. Maka, berdasarkan fenomena ini generasi muda perlu juga melihat sisi historis untuk memahami secara penuh makna nation state.

\section{Metode}

Metode yang digunakan dalam artikel ini adalah metode penelitian kualitatif. Metode penelitian kualitatif merupakan penelitian hasil interpretasi dari data yang ada di lapangan. Metode ini juga disebut dengan metode naturalistik karena pada prosesnya dilakukan dengan kondisi alami atau apa adanya sesuai dengan keadaan di lapangan (Sugiyono, 2015). Maka dari itu, dalam artikel ini penulis memaparkan hasil penelitian berupa konsep peleburan cakrawala yang ditawarkan oleh Hans Georg Gadamer dan hasil kritik penulis terhadap konsep yang ditawarkan Hans Georg Gadamer, yakni konsep peleburan cakrawala.

Adapun pengumpulan data dalam artikel ini menggunakan studi pustaka. Studi pustaka ialah segala usaha yang dilakukan untuk menghimpun informasi yang relevan dengan topik atau masalah yang akan atau sedang diteliti, data tersebut diperoleh melalui buku-buku ilmiah, laporan penelitian, jurnal, ketetapan-ketetapan, peraturan-peraturan, dan sumber lainnya baik itu bentuk cetak maupun non-cetak (Anggraini, 2020). Sehingga dalam artikel ini penulis akan mengumpulkan data melalui berbagai sumber, seperti buku, artikel, maupun sumber lainnya yang penulis anggap relevan dengan topik yang dikaji dalam artikel ini. Sedangkan metode analisis yang digunakan dalam artikel ini adalah analisis kritik, yaitu penulis akan mengkritisi atau menganalisis konsep peleburan cakrawala yang ditawarkan oleh Hans Georg Gadamer. 


\section{Pembahasan}

\section{a. Konsep Peleburan Cakrawala Berdasarkan Perspektif Hans Georg Gadamer}

Hans Georg Gadamer yang dikenal sebagai seorang filsuf hermeneutika ini mengungkapkan beberapa teori dan konsep, salah satunya adalah konsep peleburan cakrawala atau horison. Menurut Gadamer cakrawala yang saat ini dimiliki oleh setiap orang merupakan dari hasil terbentuknya akumulasi berbagai cakrawala pada masa lalu dalam gerak melingkar yang terus-menerus, sehingga dalam hal ini cakrawala tidak berhenti begitu saja, la akan terus ada berdasarkan keadaan pada masa lalu (Budiantoro, 2021). Dengan kata lain, cakrawala ini akan terbentuk tanpa adanya cakrawala pada masa lampau. Cakrawala atau horison pada dasarnya menurut Gadamer dapat diartikan sebagai jangkauan pandangan atas suatu titik atau objek tertetu. Sehingga cakrawala ini akan menjelaskan makna maupun maksud dari titik atau objek pandang, dan dapat dikatakan apabila seseorang yang memiliki cakrawala maka la akan dapat melihat cukup jauh atau luas terhadap titik tersebut, begitu pula sebaliknya, dan ini berarti apabila seseorang memiliki cakrawala yang jauh dan luas maka la akan mampu melihat bagian-bagaian yang terhubung dengan titik atau objek tersebut.

Pada ruang hermeneutika Hans Georg Gadamer mengatakan bahwa pencapaian cakrawala seseorang akan dilalui dengan cara sebuah penyelidikan dan mencermati pertanyaan-pertanyaan yang ditimbulkan dari penafsiran atau pemaknaan tentang suatu objek. Akan tetapi, pernyataan bahwa seseorang dapat memahami suatu objek dengan menggunakan cakrawalanya belum dapat disebut dengan pemaham atau penafsiran yang benar atau satu-satunya. Hal ini dikarenakan cakrawala hanya bagaikan sebuah sudut pandang khusus. Seperti yang disampaikan di atas, cakrawala pada masa sekarang tidak akan terbentuk tanpa adanya cakrawala pada masa lampau. Untuk memahami masa lalu tersebut menuntut pula adanya cakrawala historis tertentu. Perlunya cakrawala historis ini dimaksudkan Gadamer untuk menempatkan diri kita pada keadaan masa lalu. Sederhananya untuk memahami dan memberi pengertian terhadap seseorang tentang bagaimana keadaan pada masa lalu.

Sebagai contohnya, cakrawala seseorang dalam konteks historis atau sejarah yaitu saat memahami suatu karya seni maka cakrawala historis seseorang digunakan sebagai perangkat yang meleburkan titik estetik dari karya seni tersebut. Hal ini berarti terjadi peleburan antara cakrawala tersebut dengan cakrawala arus makna tradisi tertentu dari karya seni tersebut pada masa sekarang. Setiap pertemuan cakrawala dari masa ke masa dengan tradisi pemaknaan tertentu terjadi peleburan cakrawala. Pertemuan cakrawalacakrawala tersebut akan terus-menerus terbentuk dari cakrawala-cakrawalanya pada masa lalu. Adapun bagian terpenting dari ini adalah pertemuan antara dua cakrawala tersebut, bukan dari apa hasil pemaknaannya.

Maka dari itu, berdasarkan paparan di atas, Gadamer menyimpulkan bahwa cakrawala masa lalu tidak akan dapat dipisahkan dengan cakrawala pada masa sekarang, keduanya sudah seperti satu-kesatuan. Dengan kata lain cakrawala yang dimiliki seseorang pada masa sekarang tidak dapat terbentuk tanpa adanya cakrawalanya pada masa lalu. Akan tetapi di samping itu semua, pertemuan dua masa cakrawala tersebut akan terjadi peleburan pemaknaan cakrawala. Hal ini tentu terjadi dalam sebuah kesadaran historis yang mau tidak mau menyertakan dua kutub jagat makna, yaitu teks yang dipahami dan makna seorang penafsir yang akan membentuk cakrawalanya (Kaprisma, 2011). Kemudian berkaca dari apa yang disampaikan Gadamer, hal tersebut dapat dimengerti dengan melihat hubungan di antara kedua hal itu. Di sisi lain, seseorang dengan kesadaran historisnya harus bersikap waspada atas keunikan cakrawalanya sendiri yang pada gilirannya mampu membedakan dirinya dengan cakrawala tradisi, dan secara tidak langsung inilah yang menjadi bagian dari tugas kesadaran sejarah-efektif (effectivehistorical consciousness).

Selanjutnya Gadamer menekankan bahwa suatu penafsiran maupun pemaknaan bukanlah suatu elemen tambahan yang dilakukan setelah seseorang memahami suatu objek. Dalam cakrawala hermeneutika proses untuk mencapai suatu pengertian yang utuh selalu terkandung unsur pemahaman, penafsiran, dan penerapan (Kaprisma, 2011), sehingga tidak dapat dipisahkan di antara ketiga elemen tersebut. Secara sederhannya, untuk mencapai suatu pengertian yang utuh harus dilakukan dengan metode pemahaman terlebih dahulu, kemudian dengan metode penafsiran, dan selanjutnya setelah pemahaman dan penafsiran tersebut seseorang akan diantarkan menuju tahap penerapan / pengaplikasiannya. Menurut Gadamer tahapan ini seperti yang telah diketahui bahwa 
tindakan untuk mengerti suatu objek dalam hal ini teks selalu mengandung suatu penerapan dalam kaitannya dengan situasi orang yang ingin mengerti teks tersebut. Dengan kata lain, melalui elemen penerapan ini kita diajak melihat bahwa pengertian beraspek konteksual.

Oleh karena itu, berdasarkan paparan tersebut terhadap konsep peleburan cakrawala dalam pespektif Hans Georg Gadamer, dapat simpulkan bahwa Hans Georg Gadamer menitik beratkan pada setiap adanya pemahaman atau penafsiran cakrawala pada masa sekarang tidak lepas dari pemahaman atau penafsiran cakrawala pada masa lalu, yaitu dalam konteks historis, dan pertemuan antara dua pemahaman atau penafsiran akan terjadi peleburan cakrawala. Seseorang dalam menyikapi hal tersebut dibutuhkan sebuah kesadaran yang namanya kesadaran historis. Sehingga dalam konsep peleburan cakrawala yang ditawarkan Hand Georg Gadamer ini, peneliti mendukung dan sepakat terhadap perspektifnya yaitu setiap "pemahaman" sekarang tentu tidak lepas dari "pemahaman" pada masa lalu, karna masa lalu seperti menjadi landasan untuk beranjak kepada "pemahaman" pada masa sekarang, hal ini tentunya tidak dapat dipisahkan terlebih karna manusia sebagai pelaku di dalamnya bersifat dinamis. Namun "pemahaman" kedua masa tersebut benar adanya bahwa terdapat peleburan atau semacamnya, namun untuk menyikapi hal itu dibutuhkan kesadaran dari setiap individunya.

\section{b. Kritik Hermeneutika Filsafat Hans Georg Gadamer}

Berdasarkan konsep yang ditawarkan oleh Hans Georg Gadamer, dapat dipahami bahwa Hans Georg Gadamer menitikberatkan pada setiap adanya pemahaman atau penafsiran cakrawala pada masa sekarang tidak lepas dari pemahaman atau penafsiran cakrawala pada masa lalu, yaitu dalam konteks historis, dan pertemuan antara dua pemahaman atau penafsiran tersebut akan terjadi peleburan cakrawala. Seseorang dalam menyikapi hal tersebut dibutuhkan sebuah kesadaran yang namanya kesadaran historis. Sehingga dalam konsep peleburan cakrawala yang ditawarkan Hand Georg Gadamer ini setiap "pemahaman" sekarang tentu tidak lepas dari "pemahaman" pada masa lalu, karna masa lalu seperti menjadi landasan untuk beranjak kepada "pemahaman" pada masa sekarang.

Adapun dalam konsep hermeneutika Hans Georg Gadamer ini peleburan cakrawala yang la tawarkan menekankan pada pemahaman atau penafsiran yang melihat dengan menggunakan sisi kesadaran historis. Akan tetapi, jika dicermati kembali dan pada kenyataannya dalam memahami suatu objek atau dapat dikatakan dalam memahami suatu teks tidak akan pernah ada konteks historis yang sepenuhnya memadai untuk digunakan dalam pemahaman atau penafsiran suatu objek. Sehingga dalam suatu peleburan cakrawala historis hanyalah sebatas seseorang yang berada pada tahap la memiliki kesadaran pada masa lampau (historis).

Maka dari itu, sama halnya seperti apa yang dinyatakan oleh Georgia Warnke dalam bukunya yang berjudul Gadamer: Hemeneutics, Tadition and Reason (1987) bahwa peleburan cakrawala yang dimaksudkan Hans Georg Gadamer adalah sebagai hubungan historis dalam sebuah pemahaman suatu teks (Warnke, 1987). Jadi, peleburan tersebut berada di titik tengah antara masa lalu dan masa sekarang sebagai usaha untuk memahami teks dengan kesadaran historisnya. Di sisi lain, Hans Georg Gadamer membangun sebuah konsepsi bahwa "pemahaman" bukan merupakan sebuah rekonstruksi makna suatu teks melainkan sebuah mediasi, karna sebuah "pemahaman" adalah sebuah sejarah yang tidak dapat dipisahkan, baik itu antara teks maupun ia sebagai penafsir. Maka dari itu, "pemahaman" merupakan suatu langkah awal memasuki peristiwa transmisi dari masa lalu yang tidak terpisahkan dengan masa sekarang.

Sejalan dengan pemikiran di atas, dalam sebuah peleburan cakrawala memiliki persimpangan konsep yang berbeda. Hal ini seperti yang diungkapkan Jean Grondin dalam "pemahaman" cakrawala pada masa silam atau masa lalu justru membutuhkan pengertian atau pemahaman manusia terhadap cakrawala masa sekarang. Adapun konsep ini dicontohkan oleh Jean Grondin dalam bukunya yang berjudul Gadamer's Basic Understanding of Understanding yakni sebagai berikut.

"The example of a Plato interpretation is a good case in point. If some student asks a teacher about a good introduction to Plato, one can hardly ever recommend a book from the 18 or 19 century, one will generally always think of a more recent one, because it is a book that 
better conveys for us today the thought developed by Plato (the same is obvious in history). This does not necessarily imply that we undertanding Plato <<better>> than other epochs did, but simply that these recent interpretations articulate an understanding of Plato and his subject matter to which we can relate and that has an appeal worthy of the title of objectivity because it gives us a better idea of Plato. ... (Grondin, 2002)"

Berdasarkan paparan tersebut dapat dipahami bahwa Jean Grondin mencontohkan sebuah pemahaman terhadap Plato. Apabila terdapat siswa yang bertanya kepada gurunya tentang teks yang bagus digunakan untuk memahami Plato, maka Sang Guru atau seseorang kerap kali akan merekomendasikan teks yang lebih baru pada masa kini, dan jarang sekali untuk merekomendasikan teks dari abad 18 atau 19 untuk memahami Plato. Hal ini tentunya dikarenakan teks yang direkomendasikan tersebut akan menjadi lebih baik untuk dipahami dalam konteks hari ini. Akan tetapi, hal ini bukan berarti memahami Plato pada masa sekarang lebih baik dari pada memahaminya pada zaman lain atau lampau, tetapi ini hanyalah interpretasi terbaru dalam mengartikulasikan pemahaman tentang Plato.

Secara sekilas, konsep peleburan cakrawala Jean Grondin ini jelas berbeda dengan Hans Georg Gadamer yang menekankan bahwa cakrawala seseorang pada masa sekarang terjadi atas dasar cakrawala yang la miliki pada masa lalu. Sedangkan Jean Grondin menekankan bahwa memahami cakrawala pada masa lalu membutuhkan cakrawala pada masa sekarang. Akan tetapi jika ditarik ke belakang lagi, konsep Hans Georg Gadamer ini memang perlu untuk diaplikasikan. Jika diilustrasikan, dalam memahami karya seni berbahan kayu (pada masa sekarang) seseorang membutuhkan cakrawala historisnya (masa lalu) untuk mengerti dan mampu memahami karya seni tersebut, baik itu dari segi makna maupun nilai yang terkandung di dalamnya. Akan tetapi apabila seseorang tidak mempunyai cakrawala historis maka la hanya melihat sebongkah kayu dengan ukiran yang tidak memiliki arti apapun dalam karya seni tersebut.

Disamping itu, dalam ilustrasi yang digambarkan Jean Grondin di atas sangat jelas pula menyatakan bahwa untuk memasuki dan memahami sebuah teks dapat dilakukaan dengan tidak mengabaikan periode kekinian. Akan tetapi, seperti ilustrasi di atas, memahami Plato dengan teks yang lebih baru pada masa sekarang bukan berarti karena alasan teks yang baru tersebut lebih baik dari teks yang lama, melainkan teks yang baru tersebut lebih menyajikan sesuatu yang berhubungan dengan zaman kekinian pembacanya. Hal ini berati pula bahwa teks yang baru akan mampu menjadi petunjuk dalam memahami teks yang lama, yang mana teks lama tersebut tentunya mengandung intisari yang lebih kompleks.

Melihat kedua konsep yang ditawarkan Hans Georg Gadamer dan Jean Grondin tersebut tentu sangat mudah dipahami karena faktor bertolakbelakangnya terhadap peleburan cakrawala dalam hermeneutika filsafat. Peleburan cakrawala Jean Grondin sepertinya lebih mudah diterima dan lebih dibutuhkan manusia pada masa sekarang. Hal ini dapat dilihat dari perkembangan ilmu pengetahuan dan teknologi yang saat ini cukup pesat, serta keadaan manusia sebagai makhluk dinamis saat ini lebih terhubung dan bersinggungan langsung dengan dunia kekinian, yang mana dalam memahami sesuatu mereka kerap kali merujuk pada teks yang baru terlebih dahulu. Apalagi ditambah dengan adanya gawai pintar sebagai produk dari perkembangan teknologi informasi yang dimiliki setiap manusia. Mereka akan lebih mudah mencari teks (informasi) yang baru dalam memahami sesuatu. Hal ini senada dengan pendapat Bahtiar bahwa perkembangan teknologi informasi memberikan kemudahan dalam mengakses informasi, baik itu berupa teks, gambar, atau lain sebagainya kapanpun dan dimanapun (Bahtiar, 2018). Akan tetapi, pencarian teks (informasi) baru yang dimaksud tersebut tidak terlepas dari pada memahami atau menerangi teks masa lalu, yakni berdasarkan dengan konteks manusia pada masa sekarang.

Adapun untuk konsep yang ditawarkan oleh Hans Georg Gadamer apabila dicontohkan dengan apa yang terjadi di Indonesia saat ini dapat dilihat dari beberapa kasus kekerasan pada anak. Sekarang ini di Indonesia masih ramai diperbincangkan kasus kekerasan pada anak bahkan dalam 7 bulan terakhir terhitung dari Agustus 2020 terdapat 4.116 kasus kekerasan anak yang tercatat oleh Kementrian Pemberdayaan Perempuan dan Perlindungan Anak (PPPA) seperti yang dilansir oleh Kompas.com (12/08/2020). Melihat riwayat kasus kekerasan anak tersebut untuk dapat mengkaji atau menelitinya baik 
itu mengenai faktor penyebab terjadinya, pihak yang bertanggung jawab, atau hukuman dan sanksi atas pelaku maka terlebih dahulu perlu memahami mengenai Undang-Undang atau dasar hukum atas perlindungan anak, salah satu contohnya adalah memahami Undang-Undang Republik Indonesia Nomor 35 Tahun 2014 tentang Perlindunan Anak, yang sebelumnya merupakan Undang-Undang Republik Indonesia Nomor 23 Tahun 2002.

Berdasarkan kasus di atas, jika disandingkan dengan konsep Hans Georg Gadamer yakni dalam memahami cakrawala pada masa sekarang perlu terlebih dahulu memahami cakrawala pada masa lalu dalam konteks historisnya, maka untuk mengkaji cakrawala yang dalam hal ini berupa kasus kekerasan anak, seseorang perlu memahami dasar-dasar hukum atau undang-undang yang berlaku terhadap perlindungan anak terlebih dahulu. Dasar-dasar hukum atau Undang-Undang tersebut tentunya sudah dikeluarkan puluhan tahun yang lalu (pada masa lalu) atau disebut sebagai cakrawala masa lalu. Hal ini bertujuan agar tidak ada salah langkah dalam menentukan keputusan atau mengambil kesimpulan terhadap kasus kekerasan anak yang terjadi, serta dapat menjadi bukti otentik dalam melakukan kajian atau penelitian.

\section{Simpulan dan Saran}

Berdasarkan paparan di atas maka dapat disimpulkan bahwa dalam dunia filsafat manusia tidak terlepas dari yang namanya menafsirkan, menginterpretasi, atau yang disebut dengan hermeneutika. Hermeneutika yang merupakan bangunan dari epistimologi ini banyak dikaji oleh para filsuf, salah satunya Hans Georg Gadamer (1900-2002) yang menawarkan konsep peleburan cakrawala. Konsep peleburan cakrawala yang ditawarkan Hans Georg Gadamer ini adalah cakrawala yang saat ini dimiliki oleh setiap orang yang merupakan hasil terbentuknya akumulasi berbagai cakrawala pada masa lalu dalam gerak melingkar yang terusmenerus sehingga dalam hal ini cakrawala tidak berhenti begitu saja, la akan terus ada berdasarkan keadaannya pada masa lalu. Cakrawala pada masa sekarang tidak akan terbentuk tanpa adanya cakrawala pada masa lampau.

Persoalan peleburan cakrawala pada kenyataannya memiliki persimpangan yang berbeda, bahkan bertolak belakang. Hal ini seperti yang dinyatakan Jean Grondin dalam "pemahaman" cakrawala pada masa lalu yang membutuhkan pengertian atau pemahaman manusia terhadap cakrawala masa sekarang. Sejalan dengan itu, peleburan cakrawala Jean Grondin ini sepertinya lebih mudah diterima dan lebih dibutuhkan manusia pada masa sekarang. Hal ini dapat dilihat dari perkembangan ilmu pengetahuan dan teknologi yang saat ini cukup pesat, serta keadaan manusia sebagai makhluk dinamis saat ini lebih terhubung dan bersinggungan langsung dengan dunia kekinian. Dalam memahami sesuatu, mereka kerap kali merujuk pada teks yang baru terlebih dahulu.

\section{Daftar Pustaka} Anggraini,
https://www.academia.edu/11500074/Kajian_Pustaka_literature_review_ G.

Ariani, P. D. (2021). Apa sih Hermeneutika Itu...? - Kompasiana.com. https://www.kompasiana.com/putridwiariani/54f75c7ca333112e358b4688/apa-sihhermeneutika-itu

Bahtiar. (2018). Teknologi Informasi dan Komunikasi. Al-Hikmah : Media Dakwah, Komunikasi, Sosial Dan Budaya, 9(1).

Budiantoro, W. (2021). HERMENEUTIKA GADAMER: PELEBURAN CAKRAWALA. In Badan Pengembangan dan Pembinaan Bahasa, Kementerian Pendidikan dan Kebudayaan. http://badanbahasa.kemdikbud.go.id/lamanbahasa/artikel/3335/hermeneutika-gadamerpeleburan-cakrawala

Gazali, R. (2012). Epistemimologi Hermeneuitika Gadamer (Kaitan dan Implikasinya bagi IImu Pendidikan secara Umum dan Khusus). Jurnal Shautut Tarbiyah - IAIN Kediri, 18(1).

Grondin, J. (2002). Gadamer's Basic Understanding of Understanding. Cambridge University Press. http://www.mapageweb.umontreal.ca/grondinj/pdf/gadamer_understanding.pdf

Hasanah, H. (2017). Hermeneutik Ontologis-Dialektis Hans-Georg Gadamer (Produksi Makna Wayang sebagai Metode Dakwah Sunan Kalijogo). Jurnal Attaqaddum UIN Walisongo 
Semarang, 9(1).

Kaprisma, H. (2011). Cakrawala Historis Pemahaman: Wacana Hermeneutika Hans-Georg Gadamer. Jurnal Literasi, 1(2).

Khalif, A. (2019). Apa Itu Filsafat? In osc.medcom.id. https://osc.medcom.id

Liana, S. I. (2011). Biografi Hans Georg Gadamer. https://www.scribd.com/doc/58713680/Biografi-Hans-Georg-Gadamer

S.S, D. (2005). Kamus Lengkap Bahasa Indonnesia. Surabaya: Apollo.

Sugiyono. (2015). Metode Penelitian Pendidikan: Pendekatan Kuantitatif, Kualitatif, dan R\&D. Bandung : Alfabeta.

Thalib, A. A. (2018). Filsafat Hermeneutika dan Semiotika. LPP Mitra Edukasi.

Wahid, A. (2017). Pengertian dan Penjelasan Hermeneutika (Upaya Penafsiran Teks). https://www.portal-ilmu.com/2017/12/pengertian-dan-penjelasan-hermeneutika_27.html

Warnke, G. (1987). Gadamer: Hermeneutics, Tradition, and Reason. https://philpapers.org/rec/WARGHT-4 